Шевченко Жанна Михайлівна кандидат педагогічних наук, старший викладач кафедри соціології та соціальної роботи Інституту гуманітарних та соціальних наук, Національний університет "Львівська політехніка", вул. Степана Бандери, 12, Львів, 79000, тел.: (095) 073-16-66, e-mail: nomar7676@ukr.net, https://orcid.org/0000-0002-4019-639X

\title{
ОСНОВНІ ПАРАДИГМИ СОЦІАЛЬНОЇ ПЕДАГОГІКИ В КОНТЕКСТІ СОЦІАЛЬНОЇ РОБОТИ
}

Анотація. У розвитку сучасної педагогічної науки можна виділити ряд тенденцій. Відбувається зближення різних областей знання, в яких основним предметом вивчення виступає людина. Так, в надрах педагогічного знання з'являються області дослідження, що використовують підходи до вирішення теоретичних і практичних наукових завдань, які інтегрують методологію двох і більше наук про людину. До таких наук відноситься і соціальна педагогіка. Джерела соціального напряму в педагогіці мають глибоке коріння. Вивчення $\mathrm{i}$ систематизація матеріалів, які розкривають джерело соціальної педагогіки, дозволили виділити кілька підходів: розвиток ідей в педагогіці, виходячи 3 потреб соціального фактору розвитку особистості; затребуваність суспільства у вихованні підростаючого покоління; формування і розвиток соціології як науки і практики. Соціальна педагогіка як освітній комплекс відображає науково освітню діяльність людей і інститутів соціума. Об'єктом соціальної педагогіки як освітнього комплексу є наукові, науково-емпіричні знання в області соціуму, соціальних відносин в ньому, соціальна робота. Сьогодні, соціальна педагогіка актуальна як ніколи і причиною тому вплив КОВІД-19, які суттєво змінив соціальні правила функціонування кожного 3 нас. Через вплив пандемії та настання карантину, ми маємо змінювати наші правила введення педагогічної діяльності і по своїй сутності, сьогодні, кожна тип такої діяльності має соціальний характер. Метою дослідження є характеристика основних аспектів соціальної педагогіки в контексті соціальної роботи. В результаті, було охарактеризовано основні елементи і особливості соціальної педагогіки в контексті соціальної роботи. Встановлено, що основна відмінність соціальної педагогіки від педагогіки: педагогіка спрямована на виховання, а соціальна педагогіка спрямована на стихійну, щодо-спрямовану та соціально контрольовану соціалізацію.

Ключові слова: педагогіка, соціальна робота, соціальна педагогіка, соціум, освіта. 
Shevchenko Zhanna Mykhailivna Ph.D., Senior Lecturer, Department of Sociology and Social Work, Institute of Humanities and Social Sciences, Lviv Polytechnic National University, Stepana Bandera St., 12, Lviv, 79000, tel.: (095) 07316-66, nomar7676@ukr.net, https://orcid.org/0000-0002-4019-639X

\title{
BASIC PARADIGMS OF SOCIAL PEDAGOGY IN THE CONTEXT OF SOCIAL WORK
}

\begin{abstract}
A number of trends can be distinguished in the development of modern pedagogical science. There is a convergence of various fields of knowledge, in which the main subject of study is a person. So, in the depths of pedagogical knowledge, areas of research appear, they use approaches to solving theoretical and practical scientific problems that integrate the methodology of two or more human sciences. Social pedagogy also belongs to such sciences. The sources of social direction in pedagogy are deeply rooted. The study and systematization of materials revealing the source of social pedagogy made it possible to single out several approaches: the development of ideas in pedagogy, based on the needs of the social factor of personality development; the demand for society in the upbringing of the younger generation; the formation and development of sociology as a science and practice. Social pedagogy as an educational complex reflects the scientific and educational activities of people and institutions of society. The object of social pedagogy as an educational complex is scientific, scientific and empirical knowledge in the field of society, social relations in it, social work. Today, social pedagogy is more relevant than ever and the reason for this is the influence of COVID-19, significantly changed the social rules of the functioning of each of us. Due to the influence of the pandemic and the onset of quarantine, we must change our rules for the introduction of pedagogical activities and, in essence, today, each type of such activity has a social character. The aim of the study is to characterize the main aspects of social pedagogy in the context of social work. As a result, the main elements and features of social pedagogy in the context of social work were characterized. It was found that the main difference between social pedagogy and pedagogy: pedagogy is aimed at education, and social pedagogy is aimed at spontaneous, directed and socially controlled socialization.
\end{abstract}

Keywords: pedagogy, social work, social pedagogy, society, education.

Постановка проблеми. Як традиція мислення і дії, соціальна педагогіка старше, ніж поняття або використання терміна «соціальна педагогіка». Засновники традиції задавали правильні питання, хоча і не використовували цей термін. 3 самого початку соціальна педагогічна перспектива була заснована на спробах знайти освітні вирішення соціальних проблем. Так, педагоги, що звернули увагу на бідність і інші форми соціального неблагополуччя, наприклад Хуан Луїс Вівес, Йоганн Амос Коменський, Іоганн Генріх Песталоцці, Фрідріх Фребель, 3 педагогічної точки зору і без використання терміна «соціальна педагогіка», $є$ піонерами соціальної педагогічної точки зору. Історично склалося 
так, що соціальна педагогіка заснована на переконанні, що ви можете вирішальним чином впливати на соціальні обставини через освіту. Таким чином, соціальна педагогіка почалася зі спроб педагогічного протистояння соціальному лиху в теорії і на практиці. Важливість освіти в розвитку суспільства обговорювали великі філософи класичної античності. Наприклад, Платон i Аристотель обговорювали соціальну філософію через етичні, політичні та педагогічні питання. Однак вони не приділяли особливу увагу питанням бідності, соціального неблагополуччя і соціальної допомоги. Теоретичні передумови для розвитку соціального педагогічного мислення i дії не були сформовані до переходу до сучасного періоду в епоху Відродження, Реформації, а потім i Просвітництва, коли ідеї соціального прогресу стали асоціюватися 3 діяльністю людства. Виникли два типи стратегій для вирішення соціальних проблем i сприяння соціальному благополуччю: політика i педагогіка. Саме тому, дуже актуальним є обрана тематика дослідження.

Аналіз останніх досліджень і публікацій. Важливі аспекти дослідження соціальної педагогіки в контексті соціальної роботи висвітлюються такими ученими як I. Звєрєва, О. Безпалько, С. Григор'єв, М. Галагузова та ін. Однак сьогодні, досі актуальним є питання визначення основних аспектів соціальної педагогіки в контексті соціальної роботи.

Метою статті є характеристика основних аспектів соціальної педагогіки в контексті соціальної роботи.

Виклад основного матеріалу. 3 точки зору соціальної історії, походження соціальної педагогічної діяльності міцно пов'язано з процесами індустріалізації та урбанізації, які викликали нові соціальні проблеми через фрагментації соціального ладу традиційного аграрного класового суспільства. У цих процесах багато дітей і дорослі, які потребують допомоги, були залишені без уваги, і було виявлено багато нових видів соціальних лих. Освіта в різних формах розглядалося як важливий механізм вирішення цих нових проблем як в сім'ях, так i в громадах. Природно, освіта та соціальна допомога також були об'єднані в теорії і на практиці, і виникли передумови для розвитку соціальних педагогічних інститутів в суспільстві. Соціальна педагогіка розвивалася як система організованої діяльності.

Деякі загальні теорії освіти включають розвиток глибокого розуміння природи соціальних проблем, хоча концепція соціальної педагогіки не використовується. 3 самого початку концепція соціальної роботи була неточною, оскільки вона використовувалася в багатьох різних контекстах, в той час як соціальну педагогіку можна розглядати як як загальну теорію освіти, так і як зведення освіти до виключно процесам індивідуального розвитку. Її також можна розглядати як галузь дослідження, в якій розглядається зв'язок між освітою i суспільством, або це може ставитися до сфери діяльності в суспільстві, що запобігає і пом'якшувальною соціальні проблеми за допомогою освітніх методів. Подібна двозначність щодо природи, діапазону і масштабів ідеї соціальної педагогіки проблематична. 3 самого початку соціальна педагогіка була покликана 
виправдати iii iснування, в результаті чого склалася глибока і плідна традиція теоретичних дебатів. Несхожі концепції людини і суспільства і різні онтологічні, епістемологічні та аксіологічні точки зору виявляються в різних теоретичних інтерпретаціях соціальної педагогіки. У деяких з цих побудов навіть закладені різні політичні та ідеологічні устремління. Це різноманітність як збагачує, так $\mathrm{i}$ ускладнює характер соціально-педагогічної дискусії. Крім того, в різних національних традиціях соціальної педагогіки є багато особливих характеристик i унікальних елементів, пов'язаних з економічними, культурними, соціальними $\mathrm{i}$ політичними факторами.

Засновники соціальної педагогіки не збиралися створювати нову професійну групу під назвою «соціальні педагоги». Спочатку цей термін використовувався для позначення теорій освіти і / або певної галузі науки про освіту. Він відповідав ідеям, заснованим на протилежних індивідуалістичних підходах до освіти. Соціальна педагогіка як концепція педагогічної теорії і області дослідження виникла як критика освіти, зосереджена на освіті 3 точки зору розвитку особистості без урахування соціальних аспектів людського існування.

У деяких європейських країнах за межами Німеччини соціальна педагогіка активно застосовувалася ще до Другої світової війни. Однак є деякі специфічні для країни тенденції. Наприклад, шведська, датська і іспанська традиції спочатку перебували під впливом теорії Наторпа, а традиції німецько- та іспаномовних культур зіграли важливу роль в теоретичному розвитку. соціальної педагогіки в Фінляндії в 1990-і роки.

Хоча соціальна педагогіка і соціальна робота можуть розглядатися як єдине ціле в сучасній концепції соціальної роботи, все ж можна задатися питанням, які характеристики соціальної допомоги, коли вони підкріплені педагогічними конструкціями. Щоб бути конкретним, соціальна педагогіка дійсно має принаймні певну власну перспективу в сучасній соціальній роботі. Це не може бути зведене до набору простих педагогічних методів, але повинно розумітися як освітня орієнтація, при якій світ, люди, суспільство, соціальні проблеми та соціальна робота розглядаються як би через «соціально-педагогічні» окуляри.

Соціальна педагогіка концентрується на питаннях інтеграції особистості в суспільство як в теорії, так і на практиці. Її мета - зменшити соціальну ізоляцію. У ній розглядаються процеси людського зросту, які пов'язують людей 3 системами, установами та спільнотами, які важливі для їх благополуччя i управління життям. Основна ідея соціальної педагогіки полягає в тому, щоб сприяти соціальному функціонуванню, залученню, участі, соціальної ідентичності та соціальної компетентності людей як членів суспільства.

Педагогічні стратегії і програми засновані на освітньому підході. У той час як політична діяльність спрямована на досягнення мети, впливаючи на зовнішні елементи суспільства, тобто на структури, інститути і законодавство, педагогічна діяльність спрямована на зміну суспільства шляхом впливу на особистість в суспільстві, тобто на людей, мораль і культуру. У соціальній роботі педагогіка займається екзистенційними ціннісними і значущими питаннями. Взаємодія між 
соціальним працівником і клієнтами $є$ освітнім 3 точки зору особистісного розвитку, побудови ідентичності і людського зросту [1-3].

Соціальна педагогічна практика заснована на соціальній педагогічній теорії. Звичайно, теорія і взаємодіють один з одним, і для формування соціальної педагогічної теорії необхідні емпіричні дослідження. Але що означає поєднання освіти і соціальної допомоги в теорії і практиці соціальної роботи? Це тягне за собою певний спосіб розуміння завдань соціальної роботи та їі положення, ролі i функції в суспільстві. Традиційно ця точка зору звертає увагу на ті аспекти соціальної допомоги, які пов'язані з цілями і засобами людського розвитку. Це означає, що в соціальній педагогічної традиції походження, вираз форм i наслідків соціальних проблем розглядаються з точки зору людського дозрівання і освіти. Крім того, освітні методи використовуються в стратегіях запобігання та виправлення соціальних проблем і подолання соціальних лих.

Суб'єктивність, повсякденна життєва орієнтація міцно влаштувалися в формуванні теорій соціальної педагогіки. Перехід до соціальної науці, досягнутий шляхом обгрунтування основ теорії соціальної педагогіки в соціологічному аналізі, був логічним наслідком вихідної концепції соціальної педагогіки, який повинен був об'єднати соціальну та освітню сфери життя. Таким чином, також надання соціальної допомоги концептуалізується все більш соціологічно, в той час як в педагогічних теоріях, хоча, можливо, в меншій мірі на практиці, ідея освітніх відносин між соціальним працівником і клієнтом як фундаментальний підхід до надання соціальної допомоги дає спосіб зробити більший акцент на важливості впливу на структурні чинники суспільства. Іншими словами, соціальна допомога стала радикальної. Подібна радикалізація соціальної допомоги також сталася в 1970-х роках в англо-американській соціальній роботі під гаслом «радикальної соціальної роботи» [4-5].

Розглядати соціальну педагогіку як перспективу соціальної роботи не означає, що іiі слід розглядати як метод соціальної роботи. Соціальна педагогіка це не метод і навіть не набір методів. Як дисципліна вона має свою теоретичну орієнтацію на світ. Дія $є$ соціально-педагогічним не тому, що в ньому використовуються певні методи, а тому, що деякі методи вибираються i використовуються як наслідок соціальної педагогічної думки. Соціальнопедагогічна перспектива в соціальній роботі заснована на дослідженнях, в яких люди з самого початку знайомляться 3 соціальної педагогічної орієнтацією, щоб засвоїти правильний метод постановки питань і пошуку відповідей. Ідея людської гідності входить в поняття homo Educandus.

Традиційно соціально-педагогічна перспектива в соціальній роботі не тільки концентрується на тому, щоб допомогти людям вижити в складних умовах повсякденного життя, але і йде далі. Вона спрямовує на просування тих процесів розвитку в людях, які пов'язані з моральними цінностями. Виховне завдання соціальної роботи - допомогти людям досягти і зберегти досвід сенсу та гідності у своєму житті.

Висновки. Підсумовуючи, слід зазначити, що соціальна педагогіка повинна 
внести особливий внесок. Її концептуалізація може використовуватися в декількох контекстах. Ї̈̈ можна розглядати як спосіб мислення, в якому переплітаються соціальні та педагогічні точки зору, на основі яких можуть бути організовані різні види соціальної допомоги. Ідеї, що поєднують соціальну i педагогічну точки зору, можуть породити теоретичні сузір'я і привести до формування особливої галузі дослідження. Це відбувається в деяких країнах. Проте, соціальна педагогіка може процвітати як образ мислення і як галузь навчання без наявності спеціальної професії. У цьому контексті соціальна педагогіка як дисципліна буде розумітися не просто як основа певної професії, a й як предмет професійних областей, паралельних інших соціальних наук. Таким чином, соціальна педагогіка може бути інтегрована, наприклад, з утворенням в області соціальної роботи, і соціальні працівники можуть спеціалізуватися на цьому підході. Це не виключає можливості того, що в основі професії лежить концепція соціальної педагогіки. Наприклад, психологію не обов'язково повинні вивчати тільки психологи. Ці та інші питання, слід більш детальніше розглянути в подальших дослідженнях.

\section{Лimepamypa:}

1. Eriksson, L. \& Markström, A-M. Interpreting the concept of social pedagogy. In A. Gustavsson, H-E., Hermansson, \& J. Hämäläinen (Eds.), Perspectives and Theory in Social Pedagogy. 2003, 9-23.

2. Lorenz, W. Paradigms and politics: Understanding methods paradigms in an historical context: The case of social pedagogy. British Journal of Social Work, 2008, 38, 625-644.

3. Úcar, X. Social Pedagogy: Beyond Disciplinary Traditions and Cultural Contexts? In J. Kornbeck \& N. Rosendal Jensen (Eds.), Social Pedagogy for the Entire Lifespan, Volume I, 2011, 124-153

4. Davies Jones, H. 'The social pedagogues in Western Europe - some implications for European interprofessional care'. Journal of Interprofessional Care, 1994, 8 (1), 19-29.

5. Eichsteller, G. and Holthoff, S. 'Conceptual foundations of social pedagogy: A transnational perspective from Germany'. In Cameron, C. and Moss, P. (eds) Social Pedagogy and Working with Children and Young People: Where care and education meet. London: Jessica Kingsley Publishers, 2011, 33-52.

\section{References:}

1. Eriksson, L. \& Markström, A-M. (2003) Interpreting the concept of social pedagogy. In A. Gustavsson, H-E., Hermansson, \& J. Hämäläinen (Eds.), Perspectives and Theory in Social Pedagogy. 9-23. [in English]

2. Lorenz, W. (2008) Paradigms and politics: Understanding methods paradigms in an historical context: The case of social pedagogy. British Journal of Social Work, 38, 625-644. [in English]

3. Úcar, X. (2011) Social Pedagogy: Beyond Disciplinary Traditions and Cultural Contexts? In J. Kornbeck \& N. Rosendal Jensen (Eds.), Social Pedagogy for the Entire Lifespan, Volume I, 124-153 [in English]

4. Davies Jones, H. (1994) 'The social pedagogues in Western Europe - some implications for European interprofessional care'. Journal of Interprofessional Care, 8 (1), 19-29. [in English]

5. Eichsteller, G. and Holthoff, S. (2011) 'Conceptual foundations of social pedagogy: A transnational perspective from Germany'. In Cameron, C. and Moss, P. (eds) Social Pedagogy and Working with Children and Young People: Where care and education meet. London: Jessica Kingsley Publishers, 33-52. [in English] 